\title{
COVID-19 \& The Art of Unclenching Your Fist
}

\author{
Abhijit Dam ${ }^{1,2}$
}

Dr. AP, a senior doctor of a large teaching hospital, retired. A happy go lucky person with a large group of admirers consisting largely of fellow doctors, both young \& old. He is a great party man, drinks \& smoke on the house with his devoted fanfare partaking his lavish offerings. And then, one fine day, he contacts COVID-19 \& is admitted in the very hospital where he had spent 30 years of his life. He develops respiratory distress... As I rush to attend the call, I am appalled by the look of the deserted corridors \& waiting areas. I don't see any known faces, none of his fanfare for sure. He lies struggling for breath on non invasive ventilation, confused \& hypoxic. As he is intubated \& put on ventilatory support at the insistence of his son, I reflect back on those days when he used to be surrounded by his friends, treating them to drinks. But today, when he needs their support the most, he is left alone, in his suffering, to fend for himself. Truly, we are indeed a death denying society.

' $O$ death, where is your victory? $O$ death, where isyoursting?' (St.Paul, I Corinthians, 15:55)

When it began, people thought, 'It can't affect me. However, with time, they were increasingly confronted with the looming threat which threatened to disrupt the 'web of illusion' that they had created for themselves... an illusion, for the very world of existence is actually akin to an illusion, characterised by its transient nature. No wonder, our ancient sages called the world of existence 'maya'. Then came the period of 'lockdowns' \& the web of uncertainity surrounding it. People were in a fix, for in today's tech-savvy existence, fostered by science \& reasoning, they were now unprepared to spend time with 'themselves'! The very Self was now seen as an alien being \& was avoided. But as the lockdown prolonged, the monkey nature of the mind grew increasingly restless, demanding for more stimuli from the outgoing senses... and as the stimuli gradually dwindled amidst the lockdown, most could no longer cope, for they had never tried to tame their monkey minds. The untamed minds then took them into a whirlwind of imaginative catastrophisation resulting in depression, outbursts of anger (often directed at spouses \& healthcare personnel) \& suicidal ideations.

All this because we had forgotten the ancient art of 'stilling' our mind, learning to focus within rather than without. For in a modern society tempered with scientific fervor, such qualities like mindfulness \& compassion were scoffed at. The focus was more on the physical body with modern medicine trying its best to prolong life by technological advances, often at the cost of compromising the quality of life. Dying was something that was barely discussed as death was equated as a failure of medicine! The fine art of dying was lost just as a wisp of incense merges into space.

And as the virus tightened its grip, people began falling very sick \& dying. However, now there was a new twist in the tale, for now people were dying very lonely \& painful deaths. The very relatives, whom they had loved, now feared to confront the dying. And as the dying struggled to make a sense of 'meaning' out of their suffering, they were hopelessly lost like a little boat being tossed in a violent ocean. They died in pain... physical, spiritual, psychological \& social pain. The caregivers too suffered ...the loss of the departed coupled with the manner in which the body was handled \& 'packed' by the authourities, being unable to mourn the loss in a culturally appropriate manner \& the imposed restrictions on travel \& the number of people being permitted to attend the funerals.
'Shorn of the rituals of old, death maroons us in grief.'(Jenni Russel)

Dealing with uncertainity is something that I feel, a necessary practice. It begins with the art of 'letting go', to understand that nothing, nothing 'belongs' to you. Even your own body does not belong to you as at a point of time, it refuses to listen to you \& collapses. And so does acquisitions, relationships, etc. Attempting to gratify your monkey mind by your outgoing senses is a futile practice. Gratification can only be obtained from reflecting within, spending time with the Self in solitude, just watching the thoughts come \& go, with your Self just sitting back, observing, like watching a movie unfolding. Expectations are the root cause of sorrow. Take every day as it comes, living every moment to the brim, focussing on 'little' things like watching the sun rise \& your dog wagging its tail at you. Practice gratitude \& develop compassion for all. Forgive $\&$ ask for forgiveness. That is the art of 'unclenching your fist'.

Lifting your foot to take the first step might seem like a monumental challenge, but once that is done, you begin to walk!
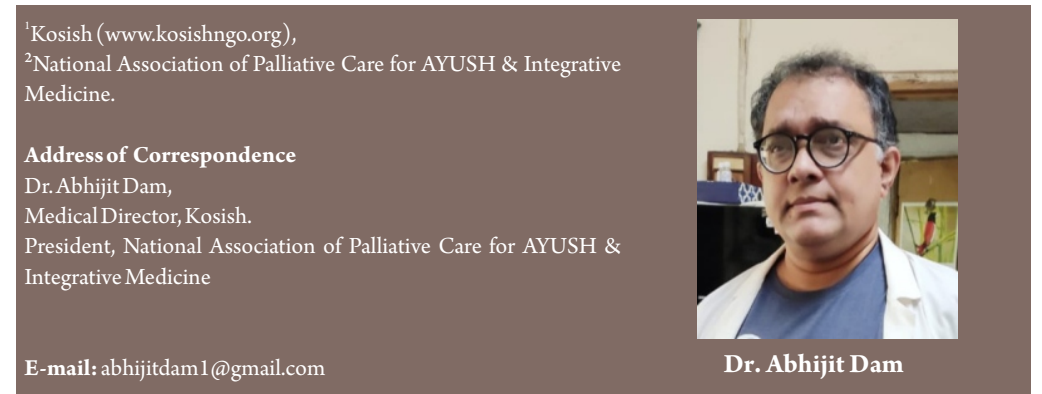

How to Cite this Article

Dam A | COVID-19 \& The Art of Unclenching Your Fist | Journal of Anaesthesia and Critical Care Case Reports | May-August 2020; 6(2): 03.

(C) 2020 by Journal of Anaesthesia and Critical Care Case Reports|Available on www.jaccr.com | DOI: 10.13107/jaccr.2020.v06i02.145 This is an Open Access article distributed under the terms of the Creative Commons Attribution Non-Commercial License (http://creativecommons.org/licenses/by-nc/3.0) which permits unrestricted non-commercial use, distribution, and reproduction in any medium, provided the original work is properly cited. 